\title{
BOUNDARY VALUE PROBLEM SOLUTION EXISTENCE FOR LINEAR INTEGRO-DIFFERENTIAL EQUATIONS WITH MANY DELAYS
}

\begin{abstract}
For the study of boundary value problems for delay differential equations, the contraction mapping principle and topological methods are used to obtain sufficient conditions for the existence of a solution of differential equations with a constant delay. In this paper, the ideas of the contraction mapping principle are used to obtain sufficient conditions for the existence of a solution of linear boundary value problems for integro- differential equations with many variable delays.

Smoothness properties of the solutions of such equations are studied and the definition of the boundary value problem solution is proposed. Properties of the variable delays are analyzed and functional space is obtained in which the boundary value problem is equivalent to a special integral equation. Sufficient, simple for practical verification coefficient conditions for the original equation are found under which there exists a unique solution of the boundary value problem.

Key words and phrases: boundary value problems, integro-differential equations, delay, solution
\end{abstract} existence.

Yuriy Fedkovych Chernivtsi National University, 2 Kotsjubynskyi str., 58012, Chernivtsi, Ukraine

E-mail: i.cherevko@chnu.edu. ua (Cherevko I.M.), uefa2012@ukr.net (Dorosh A.B.)

\section{INTRODUCTION}

Boundary value problems for differential and integro-differential equations with delay are an important part of the modern theory of differential-functional equations. Analytical solutions for such problems can only be found for the simplest types of equations, therefore the problem of finding approximate solutions is relevant. At the same time, it is important to study the solubility of boundary value problems with delay and properties of their solutions.

The study of the conditions for the existence of unique solutions of boundary value problems with delay using the contraction mapping principle was carried out in the papers $[1,5,8]$. Boundary value problems for differential and integro-differential equations of neutral type are investigated in $[2,3,7]$ with the use of topological methods. We also note the technique of a numerical-analytic method for studying boundary value problems for differential-functional equations in papers $[9,10]$. In this paper, the coefficient conditions for the existence of a solution of the boundary value problem for linear integro-differential equations with many delays, which are efficient for verification in practice, are investigated. 


\section{Problem Statement}

Let us consider the following boundary value problem

$$
\begin{aligned}
& y^{\prime \prime}(x)=\sum_{i=0}^{n}\left(a_{i}(x) y\left(x-\tau_{i}(x)\right)+b_{i}(x) y^{\prime}\left(x-\tau_{i}(x)\right)\right. \\
&\left.\left.+\sum_{j=0}^{1} \int_{a}^{b} K_{i j}(x, s) y^{(j)}\left(s-\tau_{i}(s)\right) d s\right)\right)+f(x), \\
& y^{(j)}(x)=\varphi^{(j)}(x), j=0,1, x \in\left[a^{*} ; a\right], y(b)=\gamma,
\end{aligned}
$$

where $\tau_{0}(x)=0$ and $\tau_{i}(x), i=\overline{1, n}$, are continuous nonnegative functions defined on $[a, b]$, $\varphi(x)$ is a continuously differentiable function given on $\left[a^{*} ; a\right], a^{*}=\min _{0 \leq i<n}\left\{\inf _{x \in[a ; b]}\left(x-\tau_{i}(x)\right)\right\}$, $\gamma \in \mathbb{R}$.

Let $a_{i}(x), b_{i}(x), i=\overline{0, n}, f(x)$ be continuous functions on $[a ; b]$ and $K_{i j}(x, s), i=\overline{0, n}$, $j=0,1$, be continuous functions of both arguments in the domain $[a, b] \times[a, b]$.

We introduce the sets of points determined by the delays $\tau_{1}(x), \ldots, \tau_{n}(x)$ :

$$
E_{i}=\left\{x_{j} \in[a, b]: x_{j}-\tau_{i}\left(x_{j}\right)=0, j=1,2, \ldots\right\}, \quad E=\bigcup_{i=1}^{n} E_{i} .
$$

Let the delays $\tau_{i}(x), i=\overline{1, n}$, be such that the sets $E_{i}, i=\overline{1, n}$ are finite. We number the points of the set $E$ in ascending order. Also, we introduce the notations:

$$
\begin{array}{r}
J=\left[a^{*} ; a\right], I=[a, b], I_{1}=\left[a, x_{1}\right], I_{2}=\left[x_{1}, x_{2}\right], \ldots, I_{k}=\left[x_{k-1}, x_{k}\right], I_{k+1}=\left[x_{k}, b\right], \\
B(J \cup I)=\left\{y(x): y(x) \in\left(C(J \cup I) \cap\left(C^{1}(J) \cup C^{1}(I)\right) \cap\left(\bigcup_{j=1}^{k+1} C^{2}\left(I_{j}\right)\right)\right),\right. \\
\left.|y(x)| \leq P_{1},\left|y^{\prime}(x)\right| \leq P_{2}\right\},
\end{array}
$$

where $P_{1}, P_{2}$ are positive constants. A function $y=y(x)$ from the space $B(J \cup I)$ is called a solution of the problem (1)-(2) if it satisfies the equation (1) on $[a ; b]$ (with the possible exception of the set $E$ ) and the boundary conditions (2).

\section{SOLUTION EXISTENCE}

It follows from the definition of the space $B(J \cup I)$ that the solution of the problem (1)-(2) is continuously differentiable for any $x \in[a, b]$, where $y^{\prime}(a)$ is the right derivative.

Let us introduce a norm in the space $B(J \cup I)$ :

$$
\|y\|_{B}=\max \left\{\frac{8}{(b-a)^{2}} \max _{x \in J \cup I}|y(x)|, \frac{2}{b-a} \max \left(\max _{x \in J}\left|y^{\prime}(x)\right|, \max _{x \in I}\left|y^{\prime}(x)\right|\right)\right\} .
$$


The space $B(J \cup I)$ with this norm is a Banach space. The boundary value problem (1)-(2) is equivalent to the following integral equation $[5,7]$ :

$$
\begin{aligned}
y(x) & =\int_{a^{*}}^{b}\left[\sum _ { i = 0 } ^ { n } \left(a_{i}(s) y\left(s-\tau_{i}(s)\right)+b_{i}(s) y^{\prime}\left(s-\tau_{i}(s)\right)\right.\right. \\
& \left.\left.+\sum_{j=0}^{1} \int_{a}^{b} K_{i j}(s, \xi) y^{(j)}\left(\xi-\tau_{i}(\xi)\right) d \xi\right)\right] \bar{G}(x, s) d s+l(x), \quad x \in J \cup I,
\end{aligned}
$$

where $G(x, s)$ is the Green function of the following boundary value problem $y^{\prime \prime}(x)=0$, $x \in I, y(a)=y(b)=0$. We define the operator $T$ in the space $B(J \cup I)$ in the following way

$$
\begin{aligned}
(\mathrm{Ty})(x) & =\int_{a^{*}}^{b}\left[\sum _ { i = 0 } ^ { n } \left(a_{i}(s) y\left(s-\tau_{i}(s)\right)+b_{i}(s) y^{\prime}\left(s-\tau_{i}(s)\right)\right.\right. \\
& \left.\left.+\sum_{j=0}^{1} \int_{a}^{b} K_{i j}(s, \xi) y^{(j)}\left(\xi-\tau_{i}(\xi)\right) d \xi\right)\right] \bar{G}(x, s) d s+l(x), \quad x \in J \cup I . \\
(T y)^{\prime}(x)= & \int_{a^{*}}^{b}\left[\sum _ { i = 0 } ^ { n } \left(a_{i}(s) y\left(s-\tau_{i}(s)\right)+b_{i}(s) y^{\prime}\left(s-\tau_{i}(s)\right)\right.\right. \\
& \left.\left.+\sum_{j=0}^{1} \int_{a}^{b} K_{i j}(s, \xi) y^{(j)}\left(\xi-\tau_{i}(\xi)\right) d \xi\right)\right] \bar{G}_{x}^{\prime}(x, s) d s+\frac{\gamma-\varphi(a)}{b-a}, \quad x \in J \cup I .
\end{aligned}
$$

Let the coefficients in the equation (1) be such that the following inequalities are true $\left|a_{i}(x)\right| \leq A_{i},\left|b_{i}(x)\right| \leq B_{i},\left|K_{i j}(x, s)\right| \leq \bar{K}_{i j}, i=\overline{0, n}, j=\overline{0,1},|f(x)| \leq F, x \in[a ; b]$. We denote $P=\sum_{i=0}^{n}\left(A_{i} P_{1}+B_{i} P_{2}+(b-a) \sum_{j=0}^{1} \bar{K}_{i j} P_{j+1}\right)+F$, where $P_{1}, P_{2}$ are the positive constans which are included in the definition of space $B(J \cup I)$.

Theorem 1. Let the following conditions hold:
1) $\max \left\{\max _{x \in J}|\varphi(x)|, \frac{(b-a)^{2}}{8} P+\max (|\varphi(a)|,|\gamma|)\right\} \leq P_{1}$,
2) $\max \left\{\max _{x \in J}\left|\varphi^{\prime}(x)\right|, \frac{b-a}{2} P+\left|\frac{\gamma-\varphi(a)}{b-a}\right|\right\} \leq P_{2}$,
3) $\frac{(b-a)^{2}}{8} \sum_{i=0}^{n}\left(A_{i}+(b-a) \bar{K}_{i 0}\right)+\frac{b-a}{2} \sum_{i=0}^{n}\left(B_{i}+(b-a) \bar{K}_{i 1}\right)<1$.

Then there exists a unique solution of the problem (1)-(2) in $B(J \cup I)$.

Proof. Based on Green's function

$$
G(x, s)= \begin{cases}\frac{(s-a)(x-b)}{b-a}, & a \leq s \leq x \leq b \\ \frac{(x-a)(s-b)}{b-a}, & a \leq x \leq s \leq b\end{cases}
$$


we obtain the following estimates:

$$
\int_{a}^{b}|G(x, s)| d s \leq \frac{(b-a)^{2}}{8}, \quad \int_{a}^{b}\left|G_{x}^{\prime}(x, s)\right| d s \leq \frac{b-a}{2} .
$$

When the conditions 1)-2) and the inequalities (6) are true, the operator $T$ maps the space $B(J \cup I)$ onto itself. Let $y_{1}, y_{2} \in B(J \cup I)$. Considering the estimates (6), we get

$$
\begin{aligned}
& \left|\left(T y_{1}\right)(x)-\left(T y_{2}\right)(x)\right|=\mid \int_{a^{*}}^{b}\left[\sum _ { i = 0 } ^ { n } \left(a_{i}(s)\left(y_{1}\left(s-\tau_{i}(s)\right)-y_{2}\left(s-\tau_{i}(s)\right)\right)\right.\right. \\
& +b_{i}(s)\left(y_{1}^{\prime}\left(s-\tau_{i}(s)\right)-y_{2}^{\prime}\left(s-\tau_{i}(s)\right)\right) \\
& \left.\left.+\sum_{j=0}^{1} \int_{a}^{b} K_{i j}(s, \xi)\left(y_{1}^{(j)}\left(\xi-\tau_{i}(\xi)\right)-y_{2}^{(j)}\left(\xi-\tau_{i}(\xi)\right)\right) d \xi\right)\right] \bar{G}(x, s) d s \mid \\
& \leq \int_{a^{*}}^{b}\left[\sum _ { i = 0 } ^ { n } \left(A_{i}\left|y_{1}\left(s-\tau_{i}(s)\right)-y_{2}\left(s-\tau_{i}(s)\right)\right|+B_{i}\left|y_{1}^{\prime}\left(s-\tau_{i}(s)\right)-y_{2}^{\prime}\left(s-\tau_{i}(s)\right)\right|\right.\right. \\
& \left.\left.+\sum_{j=0}^{1} \int_{a}^{b}\left|K_{i j}(s, \xi)\right|\left|y_{1}^{(j)}\left(\xi-\tau_{i}(\xi)\right)-y_{2}^{(j)}\left(\xi-\tau_{i}(\xi)\right)\right| d \xi\right)\right]|\bar{G}(x, s)| d s \\
& \leq \int_{a^{*}}^{b}\left[\sum _ { i = 0 } ^ { n } \left(A_{i} \max _{s \in J \cup I}\left|y_{1}-y_{2}\right|+B_{i} \max \left\{\max _{s \in I}\left|y_{1}^{\prime}-y_{2}^{\prime}\right|, \max _{s \in J}\left|y_{1}^{\prime}-y_{2}^{\prime}\right|\right\}\right.\right. \\
& \left.\left.+\int_{a}^{b} \bar{K}_{i 0} \max _{s \in J \cup I}\left|y_{1}-y_{2}\right| d \xi+\int_{a}^{b} \bar{K}_{i 1} \max \left\{\max _{s \in I}\left|y_{1}^{\prime}-y_{2}^{\prime}\right|, \max _{s \in J}\left|y_{1}^{\prime}-y_{2}^{\prime}\right|\right\} d \xi\right)\right]|\bar{G}(x, s)| d s \\
& =\int_{a^{*}}^{b}\left[\frac{(b-a)^{2}}{8} \frac{8}{(b-a)^{2}} \max _{s \in J \cup I}\left|y_{1}-y_{2}\right| \sum_{i=0}^{n} A_{i}\right. \\
& +\frac{b-a}{2} \frac{2}{b-a} \max \left\{\max _{s \in I}\left|y_{1}^{\prime}-y_{2}^{\prime}\right|, \max _{s \in J}\left|y_{1}^{\prime}-y_{2}^{\prime}\right|\right\} \sum_{i=0}^{n} B_{i} \\
& +\frac{(b-a)^{2}}{8} \frac{8}{(b-a)^{2}} \max _{s \in J \cup I}\left|y_{1}-y_{2}\right|(b-a) \sum_{i=0}^{n} \bar{K}_{i 0} \\
& \left.+\frac{b-a}{2} \frac{2}{b-a} \max \left\{\max _{s \in I}\left|y_{1}^{\prime}-y_{2}^{\prime}\right|, \max _{s \in J}\left|y_{1}^{\prime}-y_{2}^{\prime}\right|\right\}(b-a) \sum_{i=0}^{n} \bar{K}_{i 1}\right]|\bar{G}(x, s)| d s \\
& \leq \frac{(b-a)^{2}}{8}\left[\frac{(b-a)^{2}}{8} \frac{8}{(b-a)^{2}} \max _{s \in J \cup I}\left|y_{1}-y_{2}\right|\left(\sum_{i=0}^{n} A_{i}+(b-a) \sum_{i=0}^{n} \bar{K}_{i 0}\right)\right. \\
& \left.+\frac{b-a}{2} \frac{2}{b-a} \max \left\{\max _{s \in I}\left|y_{1}^{\prime}-y_{2}^{\prime}\right|, \max _{s \in J}\left|y_{1}^{\prime}-y_{2}^{\prime}\right|\right\}\left(\sum_{i=0}^{n} B_{i}+(b-a) \sum_{i=0}^{n} \bar{K}_{i 1}\right)\right] \\
& \leq\left\|y_{1}-y_{2}\right\|_{B} \frac{(b-a)^{2}}{8}\left[\frac{(b-a)^{2}}{8} \sum_{i=0}^{n}\left(A_{i}+(b-a) \bar{K}_{i 0}\right)+\frac{b-a}{2} \sum_{i=0}^{n}\left(B_{i}+(b-a) \bar{K}_{i 1}\right)\right] \text {. }
\end{aligned}
$$




$$
\begin{aligned}
\left|\left(T y_{1}^{\prime}\right)(x)-\left(T y_{2}^{\prime}\right)(x)\right| & \leq\left\|y_{1}-y_{2}\right\|_{B} \frac{b-a}{2}\left[\frac{(b-a)^{2}}{8} \sum_{i=0}^{n}\left(A_{i}+(b-a) \bar{K}_{i 0}\right)\right. \\
& \left.+\frac{b-a}{2} \sum_{i=0}^{n}\left(B_{i}+(b-a) \bar{K}_{i 1}\right)\right]
\end{aligned}
$$

Based on the obtained estimates, we have

$$
\begin{aligned}
& \max _{x \in J \cup I}\left|\left(T y_{1}\right)(x)-\left(T y_{2}\right)(x)\right| \\
& \leq\left\|y_{1}-y_{2}\right\|_{B} \frac{(b-a)^{2}}{8}\left[\frac{(b-a)^{2}}{8} \sum_{i=0}^{n}\left(A_{i}+(b-a) \bar{K}_{i 0}\right)+\frac{b-a}{2} \sum_{i=0}^{n}\left(B_{i}+(b-a) \bar{K}_{i 1}\right)\right], \\
& \max \left\{\max _{x \in J}\left|\left(T y_{1}^{\prime}\right)(x)-\left(T y_{2}^{\prime}\right)(x)\right|, \max _{x \in I}\left|\left(T y_{1}^{\prime}\right)(x)-\left(T y_{2}^{\prime}\right)(x)\right|\right\} \\
& \leq\left\|y_{1}-y_{2}\right\|_{B} \frac{b-a}{2}\left[\frac{(b-a)^{2}}{8} \sum_{i=0}^{n}\left(A_{i}+(b-a) \bar{K}_{i 0}\right)+\frac{b-a}{2} \sum_{i=0}^{n}\left(B_{i}+(b-a) \bar{K}_{i 1}\right)\right] .
\end{aligned}
$$

We multiply the first inequality by $\frac{8}{(b-a)^{2}}$ and the second one on $\frac{2}{b-a}$ :

$$
\begin{aligned}
& \frac{8}{(b-a)^{2}} \max _{x \in J \cup I}\left|\left(T y_{1}\right)(x)-\left(T y_{2}\right)(x)\right| \\
& \leq\left\|y_{1}-y_{2}\right\|_{B}\left[\frac{(b-a)^{2}}{8} \sum_{i=0}^{n}\left(A_{i}+(b-a) \bar{K}_{i 0}\right)+\frac{b-a}{2} \sum_{i=0}^{n}\left(B_{i}+(b-a) \bar{K}_{i 1}\right)\right], \\
& \frac{2}{b-a} \max \left\{\max _{x \in J}\left|\left(T y_{1}^{\prime}\right)(x)-\left(T y_{2}^{\prime}\right)(x)\right|, \max _{x \in I}\left|\left(T y_{1}^{\prime}\right)(x)-\left(T y_{2}^{\prime}\right)(x)\right|\right\} \\
& \leq\left\|y_{1}-y_{2}\right\|_{B}\left[\frac{(b-a)^{2}}{8} \sum_{i=0}^{n}\left(A_{i}+(b-a) \bar{K}_{i 0}\right)+\frac{b-a}{2} \sum_{i=0}^{n}\left(B_{i}+(b-a) \bar{K}_{i 1}\right)\right] .
\end{aligned}
$$

Given the resulting inequalities, we get

$$
\begin{gathered}
\max \left\{\frac{8}{(b-a)^{2}} \max _{x \in J \cup I}\left|\left(T y_{1}\right)(x)-\left(T y_{2}\right)(x)\right|\right. \\
\left.\quad \frac{2}{b-a} \max \left\{\max _{x \in J}\left|\left(T y_{1}^{\prime}\right)(x)-\left(T y_{2}^{\prime}\right)(x)\right|, \max _{x \in I}\left|\left(T y_{1}^{\prime}\right)(x)-\left(T y_{2}^{\prime}\right)(x)\right|\right\}\right\} \\
\leq\left\|y_{1}-y_{2}\right\|_{B}\left[\frac{(b-a)^{2}}{8} \sum_{i=0}^{n}\left(A_{i}+(b-a) \bar{K}_{i 0}\right)+\frac{b-a}{2} \sum_{i=0}^{n}\left(B_{i}+(b-a) \bar{K}_{i 1}\right)\right] .
\end{gathered}
$$

From the definition of the norm in the space $B(J \cup I)$ we have:

$$
\begin{aligned}
\|\left(T y_{1}\right)(x)- & \left(T y_{2}\right)(x) \|_{B} \\
& \leq\left\|y_{1}-y_{2}\right\|_{B}\left[\frac{(b-a)^{2}}{8} \sum_{i=0}^{n}\left(A_{i}+(b-a) \bar{K}_{i 0}\right)+\frac{b-a}{2} \sum_{i=0}^{n}\left(B_{i}+(b-a) \bar{K}_{i 1}\right)\right] .
\end{aligned}
$$

The inequality (7) and the condition 3) imply that the operator $T$ is a contraction in $B(J \cup I)$ and it has a single fixed point in this space [6], therefore the boundary value problem (1)-(2) has a unique solution $y(x) \in B(J \cup I)$. The proof is complete. 
Remark. An efficient algorithm for finding an approximate solution of the boundary value problem (1)-(2) is the spline approximation method, using cubic splines with defect 2, which is considered in the paper [4].

\section{REFERENCES}

[1] Athanassiadou E.S. On the existence and uniqueness of solutions of boundary value problems for second order functional differential equations. Math. Morav. 2013, 17 (1), 51-57.

[2] Cherevko I., Dorosh A. Existence and approximation of a solution of boundary value problems for delay integrodifferential equations. J. Numer. Anal. Approx. Theory 2015, 44 (2), 154-165.

[3] Dorosh A.B., Cherevko I.M. Boundary value problem solution existence for neutral delay integro-differential equations. Bukovinian Math. J. 2016, 4 (3-4), 43-46. (in Ukrainian)

[4] Dorosh A.B., Cherevko I.M. Boundary value problem solution approximation for linear integro-differential equations with many delays. Bukovinian Math. J. 2017, 5 (3-4), 77-81. (in Ukrainian)

[5] Grim L.J., Schmitt K. Boundary value problems for delay differential equations. Bull. Amer. Math. Soc. (N.S.) 1968, 74 (5), 997-1000. doi: 10.1090/S0002-9904-1968-12114-7

[6] Hartman F. Ordinary Differential Equations. Society for Industrial and Applied Mathematics, Philadelphia, 2002.

[7] Kamensky T.A., Myshkis A.D. Boundary value problems for a nonlinear neutral delay differential equation with a deviating argument. Differ. Equations Equations 1972, 8 (12), 2171-2179. (in Russian)

[8] Luchka A. On a boundary-value problem for linear differential equations with a deviating argument. In: Differential-functional and difference equations. Math. Inst. Sci. Acad USSR, Kyiv, 1981, 35-56. (in Russian)

[9] Ronto A., Ronto M., Shchobak N. On numerical-analytic techniques for boundary value problems. Acta Electrotechnica et Informatica 2012, 12 (3), 67-72. doi: 10.2478/v10198-012-0035-1

[10] Ronto A., Ronto M., Shchobak N. On finding solutions of two-point boundary value problems for a class of non-linear functional differential systems. Electron. J. Qual. Theory Differ. Equ. 2012, 13, 1-17. doi: 10.14232/ejqtde.2012.3.13

Received 24.05.2018

Черевко І.М., Аорош А.Б. Існування розв'язку крайової задачі для лінійних інтегро-диферениіальних рівнянь із багатьма запізненнями // Карпатські матем. публ. — 2018. — Т.10, №1. — С. 65-70.

Аля дослідження крайових задач для диференціальних рівнянь із запізненням застосовуються методи стислих відображень та топологічні методи для одержання достатніх умов існування розв' язку диференціальних рівнянь зі сталим запізненням. У даній роботі використовуються ідеї методу стислих відображень для одержання достатніх умов існування розв'язку лінійних крайових задач для інтегро-диференціальних рівнянь із багатьма змінними запізненнями.

Аосліджено властивості гладкості розв'язків таких рівнянь та запропоновано означення розв' язку крайової задачі. Проаналізовано властивості змінних запізнень і одержано функціональний простір, в якому крайова задача еквівалентна спеціальному інтегральному рівнянню. Знайдено легкі для практичної перевірки достатні коефіцієнтні умови на вихідне рівняння, при виконанні яких існує єлиний розв'язок крайової задачі.

Ключові слова і фрази: крайові задачі, інтегро-диференціальні рівняння, запізнення, існування розв'язку. 